Article

\title{
Evolution and Sustainability of Benefits Offered to Employees in On-Line Recruitment
}

\author{
Juan L. Tato-Jiménez, María Buenadicha-Mateos and Óscar R. González-López *D \\ Department of Business and Sociology, University of Extremadura, 06006 Badajoz, Spain \\ * Correspondence: orodrigo@unex.es; Tel.: +34-924-289-300 (ext. 86526)
}

Received: 15 May 2019; Accepted: 6 August 2019; Published: 9 August 2019

check for updates

\begin{abstract}
Corporate websites have become essential tools for the on-line recruitment process, amongst other reasons because of their ability to offer relevant information for attracting candidates. The information they display includes a section on recruitment sites usually called "Benefits Offered to Employees", the content of which has not been studied in literature. In this cross-sectional paper, we use content analysis to examine recruitment websites of the 100 Best Companies to Work For $(\mathrm{BCW})$ and direct observation to categorize these contents and analyze certain aspects: their evolution, their adaptation to the new interests (work values and attitudes, leadership and teamwork preferences, leader behaviors, and career experiences) of the new generations (Millennials and Gen Z) and their sustainability values. In addition, we apply a questionnaire to potential candidates from these generations in order to discover their appraisal of the contents of this section; we use two samples of 150 and 128 final-year students from the Degree in Business Administration and Management, who are therefore very close to being job seekers, taken at two points in time several years apart. After the analysis, it was ascertained that over half of the recruitment sites of the BCWs use this section, and that applicants rate the information on non-economic benefits more highly than that on economic benefits. Regarding sustainability activities, one outstanding point is that the sections referring to flexibility and personal life are experiencing growth. The main conclusion is that the information companies publish in this section is relevant for the new generations.
\end{abstract}

Keywords: on-line recruitment; website analyses; sustainability; benefits; best employers; millennials; generation $\mathrm{Z}$

\section{Introduction}

The reality of the 21st century has made it clear how important sustainable development is today for organizations hoping to deal with the new challenges of the environment with certain guarantees; to achieve this, they must show responsibility towards their interest groups, both socially and in the economic and environmental spheres. An organization's personnel, that is to say its employees, are one of these groups which, depending on the sustainability focus, need to be impacted responsibly and positively by the company [1]. Sustainability can be defined as "development that meets the needs of the present without compromising the ability of future generations to meet their own needs" (WCED, 1987), which implies attaining success today without jeopardizing future needs.

This study analyzes the information companies offer potential candidates on their websites, under the section usually called "Benefits Offered to Employees", and the sustainability values companies communicate in order to attract new workers. The target population of the study are the 100 companies belonging to the "Best Companies to Work For" list (BCW) published every year by FORBES.

In current literature, whilst there are some relevant studies that center on the contents of the recruitment site, it should be pointed out that the "Benefits Offered to Employees" section which is the focus of this study has been dealt with superficially and only occasionally, and from a quantitative 
stance alone, with the sole objective of ascertaining the frequency of use on recruitment sites; however, no in-depth analysis has been made of its content [2,3]. However, in our opinion, the study of the aforementioned content of this section is extremely relevant because it must at all times reflect the information on HR activities and values which the companies select for publication. It therefore also reflects the content they use to attract candidates, which should correspond to what the candidates value. As a result of all the above, an analysis must be made of the information published by companies in this section and how suited it is to the profile of the potential candidates they seek.

On the other hand, we must bear in mind that the attractiveness of the organization has a significant impact on the employee's perception of the company's performance [4]. As such, this aspect may play a relevant part in the decision to send an employment application to the firm. In this regard, the more a potential employee defends sustainability principles, the more attractive a sustainable company may be for her/him. For this reason, studies should be made of the information offered by companies and to what extent it corresponds to the new tendencies and preferences of candidates, sustainability being an important pillar of this tendency [5]. Another essential factor in the on-line recruitment process, aside from content, is the understanding of the virtual environment aspects of the website, because this affects the intentions of the potential candidates who visit said website [6]; although this factor falls outside the object of our study. At present, organizations are devoting much effort to motivating potential applicants to visit company websites so that they can find out more about them and send in their job applications [6].

As a result, the objectives of this study are:

1. To examine the contents shown on the recruitment sites of the "Best Companies to Work For", specifically in their section: "Benefits Offered to Employees".

2. To compare the alignment of the benefits offered to employees communicated by companies with the values and preferences in terms of working conditions of the new generations of candidates.

3. To study the benefits offered to employees related to the sustainability values held in esteem by potential candidates.

4. To analyze the presence of the different measures at two different points in time, in order to ascertain their evolution.

To achieve this, we first proceed to review corporate website on-line recruitment literature and the compensations offered to employees in order to attract and retain them, aside from their basic remuneration. Afterwards, a study is made of the demands of the new generations of candidates, and we study the composition, evolution and relevance for sustainability. Finally, we designed a questionnaire which was applied to potential candidates in order to ascertain the relevance of the different contents of the recruitment site.

\subsection{On-Line Recruitment through Corporate Websites}

In today's world, organizations must attempt to define the function and utility of the various tools that the Web affords them. In this way, most corporate communication processes are now centralized via the corporate website, while social network profiles and corporate blogs are focused on generating communities designed to enhance the overall on-line perception of the brand [7]. In this sense, the use of recruitment websites could help companies to expand their response to job seekers' information needs and to attract new applicants. In general, on-line recruitment is changing the way in which human resources are managed, and in particular the way in which ideal candidates are attracted to openings within companies [8-11]. New tools increase efficiency and attract and screen applicants faster in the hiring cycle, thereby contributing to streamlining their subsequent socialization [12].

Although on-line recruitment is a growing trend, research efforts related to this area are still scarce, and try to throw some light on the real value and contemporaneity of this practice [10]; not much yet is known about the properties and efficiency of these technologies in relation to more traditional 
recruitment tools [12]. Specifically, and in the context of on-line recruitment, corporate websites are an important tool and as such require specific studies.

Not only do companies have to identify their potential candidates-they must also conquer and attract them [13]. Actually, according to Maurer and Liu [14], recruitment is really marketing work and the employment sections of corporate websites are a public declaration of their self-image, of how an organization sees itself or at least, of how it would like potential candidates to see it [2].

Thus, the recruitment site is characterized by the presence of declarations aimed at communicating distinctive, unique attributes of organizations as employers [15], and by their provision of detailed descriptions of the duties to be performed in the vacant post, information on the organization, its culture, the work, the employment opportunities, and career prospects; aspects it would not be possible to transmit in offers using traditional recruitment methods [14,16-23].

Different studies reveal that conditions such as salaries, opportunities to develop one's career within the company, the structure of the enterprise or the location of the position affect the degree of attraction of applicants in any recruitment process [18,24]. Moreover, there is a positive relationship between the amount of content found in recruitment materials and the attraction felt towards an employer [22]. To improve on-line recruitment methods, Boşcai [25] also suggests an increase in recruitment site traffic of the company and the creation of a brand by the employer, with a large amount of information available for applicants. This would reinforce the relevance of the selection of the type and amount of content shown on the recruitment site. In this way, on-line recruitment via a website can become a strategic instrument in organizations.

The information supplied by the website is therefore a strategic issue, as nowadays companies try to attract talented employees who lend competitive advantages to the organization in the long term. At present, HR practices are not sufficient and a more strategic bridge is required to connect human capital with sustainable strategic success [26] and to achieve this, companies must be scrupulous about the information they offer.

To attain this strategic value, there is a need for research on improving knowledge of the factors that attract applicants who can generate value for the company [27]. On its website, the company needs to show the aspects it feels are most relevant for attracting the best employees to the openings it has to fill. As such, one key factor for attaining recruitment objectives is to select the content that will be offered, and this selection must be made according to the type of candidates sought.

One should bear in mind that by communicating about the company's activities, one can attract new employees and that they may feel more drawn to the company depending on which activities are communicated [14]. This in turn gives rise to a process which feeds on itself, as the higher the number of employees with certain values, the more likely the organization is to take these values into consideration within its strategy. However, also, as we pointed out previously, in order to achieve competitive, sustainable recruitment strategies, the content must be tailored to the preferences of the new potential candidates, whose values evolve and change from one generation to the next, and are impregnated with sustainability principles $[5,28]$.

Companies that include sustainable benefits in their recruitment messages will attract job seekers who value these aspects; among other reasons, this is due to the Person-Organization fit effect of the contents of the recruiting website. Different authors [29-31] indicate that the perceptions of Person-Organization fit candidates positively influence the behavior of job seekers and will influence the self-selection decisions and the choice of a given employer when submitting an application. Since the success of e-hiring will depend on the quality of the nature of the information and its relevance for the applicant, Highhouse \& Hoffman [32] highlight that the type of content plays a very important part in defining the candidates' interest.

To sum up, it is advisable for companies to try and adapt their websites (content and design) to the profile of the candidates they seek. To do so, companies must take into account some of the characteristics of the potential candidates, such as the motivation behind their search for employment or work experience [33]. As a result, we should be mindful that the new generations (Millennials and 
Z) already have a significant presence in companies, and that recruitment strategies must become sustainable in order to adapt to the new preferences.

\subsection{Benefits Offered to Employees}

Corporate websites contain a section indicating the benefits employees will receive for forming part of the company (in addition to whatever the basic salary for the post is); this section is usually called "Benefits offered to employees". Numerous companies which use corporate website recruitment include this specific section. According to the data from the work study by Cober [3] on the recruitment pages of the Best Companies to Work For, $77 \%$ of these companies had this section. According to Young and Foot [2], who used a sample of the companies in the Fortune 500 list, $85 \%$ of the companies included this section in the search for candidates through their website. However, the "Benefits Offered to Employees" section requires specific studies to demonstrate its value and establish guidelines on how to manage it in the on-line recruitment process.

This space on corporate websites offers a wide diversity of content which organizations consider relevant for candidates; it differentiates them from what other companies offer and may enhance the attractiveness of the company in question for the workforce. Thus, an example of one of the routes companies use to differentiate themselves from competitors and attract talent is indirect remuneration [34,35]. All of the measures geared towards achieving work-life balance are also highly relevant.

Meanwhile, as pointed out by Ehrhart and Ziegert [36], individuals choose their preferred organizations or jobs according to their perceptions of the characteristics of the environment which are important to them. These may include the location of the position, the culture, the size of the organization or the work-life balance policies, the latter being one of the contents of the recruitment sites aimed at matching the company to the candidate [3]. It may be significant to consider the possibility that the human resource policies displayed by the organization (for example, having flexible policies that favor family and personal life) could be interpreted as a sign of other characteristics such as services and concern for the company's employees [37], and that they are consequently relevant for candidates.

Therefore, for Madero and Zárate [38], implicit in the social dimension of sustainability are wellbeing, quality of life and work-life balance, all of which lead organizations to motivate and promote the wellbeing of their employees as a response to their social commitment towards this interest group. For Contreras and Rozo [39], putting strategies into practice which pursue the wellbeing of employees and their families is an important factor within organizational sustainability, strengthening the image of the company with the personnel, and dissemination of this facet is relevant for capturing new employees.

Significantly, we should point out that it would be impossible to analyze all the benefits that may exist in today's companies. This is especially the case if we consider that the possibilities of developing and implementing benefits can be almost infinite [40]; for this reason, it was necessary to classify the most relevant measures into groups. In order to analyze the contents of the section under study, they have been grouped according to a classical categorization differentiating the "Economic benefits" from the "Non-economic benefits" [41-50]. In order to attract talent, companies communicate the non-economic compensations which may comprise an important distinction as compared to other firms. Prat and Tovar [41] highlight the fact that these non-economic components cannot be bought on the marketplace, and Mondy [51] relates them to both psychological and physical factors within the company work environment. As a result of our choice of classification method, 23 types of measures have been classified using the bibliographic review (See Table 1), consultations with experts and analyses of Benefits Offered to Employees sections on recruitment sites. To delimit the sustainability of said human resource activities, diverse sources were tapped:

1. The ILO Guidebook, “Decent Work and the Sustainable Development Goals. A Guidebook on SDG Labour Market Indicators". 
2. HR programs such as performance management, selection, and training can reflect fair treatment, respect for collective association rights, and work-family balance, and reward not only economic performance, but also community involvement or reduced environmental emissions [26].

3. The Measures often appear in corporate sustainability or social responsibility reports to investors: HR can measure sustainability-related knowledge, behaviors, attitudes, and motivation, as well as collective activity, community involvement, and employee health and safety.

Table 1. Classification of the benefits offered to employees. Source: drawn up by the authors.

\begin{tabular}{cl}
\hline & \multicolumn{1}{c}{ NON-ECONOMIC BENEFITS (NEB) } \\
\hline $\begin{array}{c}\text { Employee assistance } \\
\text { programs }\end{array}$ & $\bullet \quad \begin{array}{l}\text { EAPs. Instruments organizations provide for their employees to deal with complicated work and } \\
\text { family situations which have a negative impact on their quality of life. } \\
\text { Work-life balance training. Training actions designed to improve the balance with personal and } \\
\text { family life. }\end{array}$
\end{tabular}

Commitment measures (employee / organization)
- Recognition programs. Programs designed for the organization to explicitly show interest in and appreciation for good workers.

- Employee referral programs. Programs designed for the organization to positively value employees who have suggested candidates to cover openings in the company when said candidates have subsequently turned out to be suitable for the post.

- $\quad$ Remote working. Possibility of working from a distance for some or all of the day.

- $\quad$ Sabbaticals. Possibility of taking sabbatical periods from work.

Flexibility measures $\quad$ - Flexible hours. Possibility of flexibility of work hours within the organization, to a greater or lesser extent.

- $\quad$ Leave. Offer to increase the legally-established leave for workers in the company.

\section{ECONOMIC BENEFITS (EB)}

- Reimbursement of fees. Reimbursement to employees of all or part of the sum of their fees for enrolling in courses of study.

- Discounts on own products/services. Covering of part of the price of company products and/or services acquired by employees.

Measures to facilitate saving

- Discounts on products/services of other companies. Agreements to reduce the price of the products and/or services of other, previously specified companies, for employees.

\section{- Cafeteria. Assistance in the form of a smaller or larger amount, or provision by the company of the cafeteria service (beverages and/or food) for employees. \\ Support in performing the - $\quad$ Fitness and massages. Company assistance with expenses related to improving and maintaining work employees' state of physical fitness. \\ - Transport. Assistance in the form of a smaller or larger amount, or provision by the company of the transport service (commute and/or parking) for employees.}

\begin{tabular}{|c|c|}
\hline Insurance cover & $\begin{array}{l}\text { - Health insurance. Health insurance for employees, or for employees and their family (beyond } \\
\text { the mandatory legal amount). } \\
\text { - } \quad \text { Life insurance. Life insurance for employees. } \\
\text { Pension plans. Contributions made by the company to workers' pension plans (beyond the } \\
\text { mandatory legal amount). }\end{array}$ \\
\hline $\begin{array}{l}\text { Measures to facilitate } \\
\text { personal life }\end{array}$ & $\begin{array}{l}\text { - Home help. Assistance in the form of a smaller or larger amount to cover activities in the home } \\
\text { for the candidate. } \\
\text { - Support with care for the elderly. Economic assistance designed to cover expenses arising from } \\
\text { care of the elderly. } \\
\text { - Childcare. Assistance in the form of a smaller or larger amount, or provision by the company of } \\
\text { a daycare service for employees' children. } \\
\text { Assistance with adoption. Assistance in the form of a smaller or larger amount to cover child } \\
\text { adoption processes for company employees. }\end{array}$ \\
\hline
\end{tabular}




\subsection{Demands and Sustainability of the Millennial and Z Generations}

It is important to define the generational composition within organizations, since the generational differences in work values influence the requirement-related aspects of people management such as recruitment [52]. There is some evidence that younger generations increasingly prioritize the balance between work and life, both in terms of attitude and behavior. Moreover, evidence from time-lag and cross-sectional studies suggests that, despite numerous similarities, the generations in today's workplace differ in aspects of their personalities, values and work attitudes, leadership and teamwork preferences, leadership behaviors and professional experiences [53], and also Quality Priorities of Life [54].

Therefore, an exploration of the generational distribution in the organization may be useful in order to more fully comprehend employee benefits, because as Dencker, Joshi, \& Martocchio [55] point out, a better understanding of the generations cohabiting within organizations can lead to better recruitment, retention, succession management, communication, employee engagement, and conflict resolution.

We should not lose sight of the fact that at present, the new candidates who cover open positions largely belong to the Millennial and $\mathrm{Z}$ generations and that we should assume that their needs appear different to those of other generations of applicants. Diverse studies have been reviewed in order to assess what the demands of these generations are and how they are different to those of preceding generations.

ManpowerGroup commissioned the reputation leaders of the innovative leadership consultancy to conduct a global quantitative study of 19,000 Millennials who are in work and 1500 hiring managers in 25 countries to understand what Generation $Y$ want now and in the future, and to help people and organizations achieve success in this new world of work. The research population included an independent sample of 11,000 working Millennials distributed equally over all age and gender ranges from 18 countries, representing all the regions. Also surveyed were over 8000 associated employees of ManpowerGroup Millennial and 1500 hiring managers in 25 countries. Talking to both groups gives perspectives both of employers and of employees. The field work was carried out between February and April of 2016. The participant countries were: Argentina, Austria, Australia, Belgium, Brazil, Bulgaria, Canada, China, France, Germany, Greece, India, Italy, Japan, Malaysia, Mexico, Netherlands, Norway, Paraguay, Singapore, Serbia, Spain, Switzerland, United Kingdom, and United States. The Manpower study [28] stresses that one goal of Millennials is to prioritize the time dedicated to themselves and breaks related to free time. According to this report, $40 \%$ of Millennials plan to take significant breaks for relaxation, travel or vacations. In addition, their interest in continuing their training is salient. Eighty percent indicate that the opportunity to learn new skills is an important factor when considering a new job. Twenty-two percent would take a break to go back to education and develop new skills. Ninety-three percent want to learn throughout their life and are willing to spend their own time and/or money on additional training. Career development is also relevant: When asked what the "right" amount of time is to remain in a particular role before being promoted or moving on to another, approximately two-thirds said less than 2 years, and a quarter said less than 12 months, indicating an appetite for new challenges. With regard to acknowledgment, it may be relevant that half of them would consider leaving their current employment due to lack of appreciation.

The Millennial-Survey-Report [5] study by the consultancy firm Deloitte also indicates that Millennials are asking business leaders to take the initiative to solve the world's problems and change the excessive focus of organizations on gaining profits and balance out social concerns, becoming more diverse, flexible and generous with their employees. Organizations that can offer these traits may be better placed to attract and retain the best employees of the millennial generation and generation $Z$, and in this way potentially reinforce their prospects of success in the long term. The 2018 report is based on the opinions of 10,455 Millennials surveyed in 36 countries, who have the equivalent of high school diploma, college or university degrees; are full-time employees; and work predominantly in large organizations in the private sector. This report also includes responses from 1,844 Generation $Z$ 
members surveyed in Australia, Canada, China, India, the United Kingdom, and the United States. The Generation Z members surveyed were born between January 1995 and December 1999. They are all students of or have a first/advanced degree. Over one-third of them are working full-time $(16 \%)$ or part-time (21\%).

Continuing with this survey, many of the participants are asking themselves whether they have the skills to compete in industry 4.0 and are increasingly looking to their employers to provide them with the skills they need to be successful. Whilst technical skills are always necessary, those surveyed are particularly interested in developing interpersonal skills, confidence and ethical behavior, all of which they feel is essential for a company to be successful. As for the sustainable values of the new generations and their differences with the rest, according to Deloitte [5], the young people of this generation increasingly prefer companies which comply with environmental and corporate social responsibility standards, factors which carried less weight at the end of the last century.

According to the study by Rubbermaid Commercial Products "Recycling in the Workplace: A Millennial View" [56], nine out of 10 young people feel it is important to work in a sustainable company and $10 \%$ of them, moreover, say they would leave their job if their company did not meet their sustainability and recycling expectations. In addition, the key findings of the "Recycling in the Workplace: A Millennial View" study include the following observations:

1. Sustainability is important to this generation and is a core value they consider in relation to their career. Nine out of 10 millennials say it is important that they work for a sustainable company, compared to $84 \%$ of Gen Xers and $77 \%$ of Baby Boomers.

2. Eighty-two percent of millennials look for opportunities to help their company become more sustainable and $67 \%$ report that they have enough influence in their workplace to make an impact on matters such as sustainability.

\section{Materials and Methods}

In order to tackle the goals set, we must study the range of contents companies include in the benefits offered to employees and the appraisal made of this information by the potential candidates from the new generations when making the decision to apply for an opening.

\subsection{Collection of Data from the Websites}

To carry out this study, we selected companies which stand out for their good human resource management, so that we could assume from the outset that there was concern for and excellence in factors related to employees. The recruitment sites evaluated are those of the 100 Best Companies to Work For from the year 2011 and 2018 published in the magazine Fortune.

The design and compilation of these data were conducted during 2012 and 2019 by the researchers. To compile the data, a template with dichotomous response questions was used, which was completed by means of direct observation. Within the recruitment sites, we proceeded to search for and register those with a specific "Benefits Offered to Employees" section. In the companies that have this section, we performed a content analysis and everything that appears in it was read in full, and we proceeded to evaluate each of the items selected, i.e., to record whether one of the companies did or did not provide information on different important aspects in the Benefits Offered (recorded in Table 1).

Each researcher has accessed and studied all of the sites, comparing the data with the aim of eliminating any possible errors of observation. In this way, a matrix of zeros and ones corresponding to the items and companies was obtained. 
The general consideration assumed for recording each variable is the following: if, in the Benefits Offered to Employees section of the company website, no information is provided on the factor observed, the value zero is assigned to the observation, and if the company does provide information on this aspect, a one is assigned to it.

The researchers also gathered data from the current active workforces of the 100 BCW 2018, and the generational composition was recorded to assess the presence of employees born after 1981 (generations $\mathrm{M}$ and $\mathrm{Z}$ ).

\subsection{Survey of Potential Candidates}

To ascertain the appraisal potential candidates make of the contents of the Benefits Offered to Employees sections, we designed a questionnaire which was applied to these candidates. The questionnaire was answered at two points in time with sufficient distance between them (2013 and 2019) by samples selected for this study. They are:

- Sample 1 comprised of 150 potential candidates from the Millennial generation. In terms of age, the average age of the evaluators is 23.45 years. After excluding questionnaires the researchers deemed to be invalid and/or incomplete, 138 students from the Degree in Business Administration and Management successfully completed all of the questionnaires and their data were used for the analysis. The questionnaire was given in the month of April 2013.

- Sample 2 comprised of 128 potential candidates from generation Z. After excluding questionnaires, the researchers deemed to be invalid and/or incomplete or unsuitable due to their age, 104 students from the Degree in Business Administration and Management successfully completed all of the questionnaires and their data were used for the analysis. The questionnaire was given in the month of February 2019.

According to Davis [57], use of this kind of sample is advisable in this context, as they are opinion leaders on Internet content; and, by the same token, since they are in the final months of their university education, they are very close to being job seekers, which justifies the study of candidates who are not experienced in job seeking. Moreover, amongst the most suitable profiles, on-line recruitment is mainly perceived as appropriate for young people with qualifications [58].

The self-administered questionnaire was designed to be answered on-line. This type of questionnaire has several different advantages: they are quicker, simpler and cheaper; the data collection period is shortened significantly and they are less intrusive $[59,60]$. Those surveyed evaluated the relevance of the different contents of the recruitment site on a scale of 1 to 5 , from unimportant information (1) to very important information (5), for cases where the subject was going to apply for a job using the company website (apart from basic details of the post such as name, description and location of the post).

Starting out from the premise of the validity of content of the items by bibliographical review, to support the validity of the measuring instrument, a pre-test was carried out in which those surveyed were asked to assess the relevance of different contents of the recruitment site on a Likert scale of 1 to 5, from information of little importance for the decision to apply for an opening in the company in question (1) to information that is very important for applying for an opening in the company in question (5). The results are shown in Figures 1-3. 


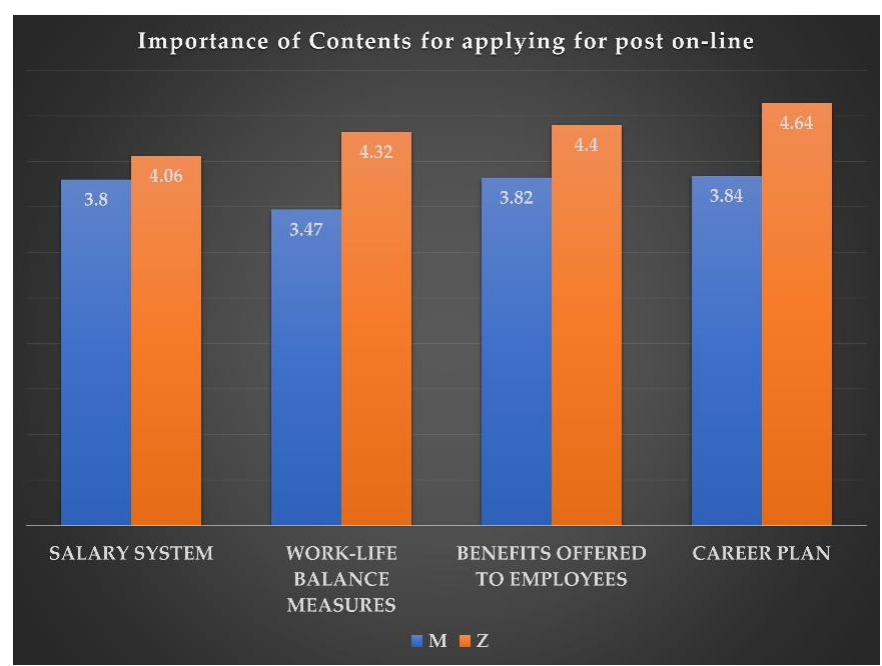

Figure 1. Evaluation of the importance of different contents on the recruitment site in applying for a position. Source: Drawn up by the authors.

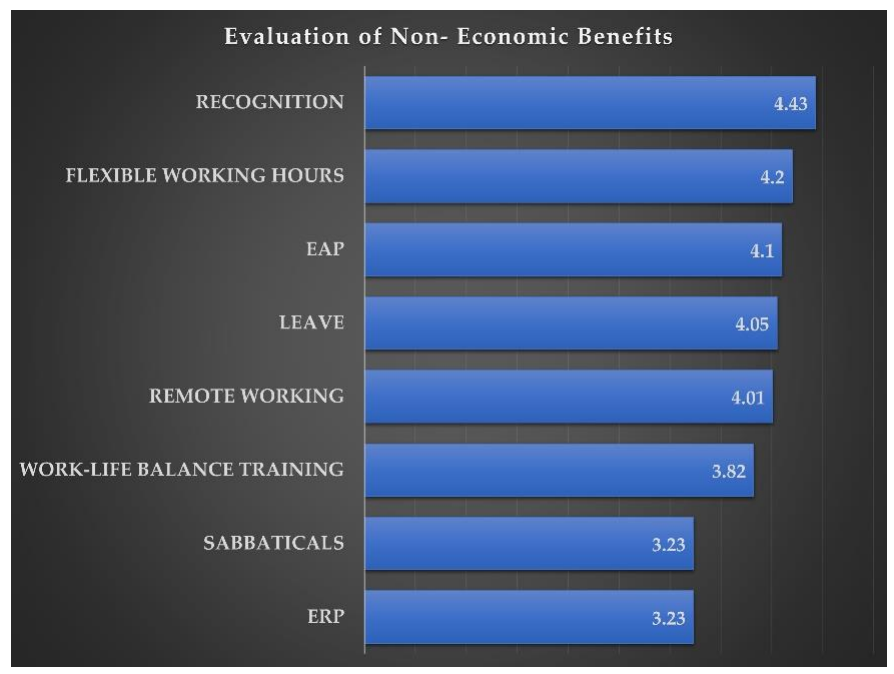

Figure 2. Evaluation of the importance of different measures involving non-economic benefits in applying for a position. Source: Drawn up by the authors.

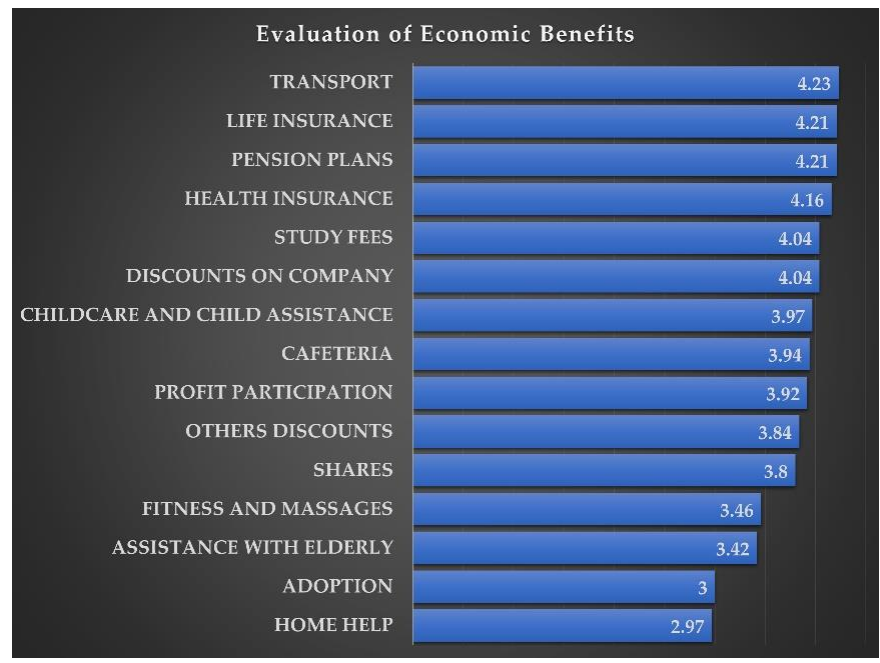

Figure 3. Evaluation of the importance of different measures involving economic benefits in applying for a position. Source: Drawn up by the authors. 


\section{Results}

As a first result in this information analysis stage, we established that $98 \%$ of the BCW 2011 and 95\% of the BCW 2018 have a recruitment page on their corporate website. The name of the access to the recruitment site at each of these points in time was analyzed in order to check whether there is diversity in the names. Generally speaking, on corporate websites one can find a link to the careers page called "careers" or "jobs" [2]. In the BCW 2011, the most frequently used name of the access to the recruitment site was Careers (85\%), followed by Jobs (11\%). In the BCW 2018, the most frequently used name of the access to the recruitment site was Careers (93.7\%) followed by Jobs (3.2\%), coinciding with the order of importance of the accesses in the study by Young and Foot (Young \& Foot, 2005). A tendency towards homogenization of the name of the recruitment site under the title of Careers can be observed.

With regards to companies which present the "Benefits offered to employees" section within the recruitment site, the work by Cober, Brown and Levy [3] on the recruitment sites of the BCW 2000 indicates that $77 \%$ of the BCW MET 2000 do have one. In this study, we quantified the utilization of the Benefits Offered to Employees section at 81.63\% for the BCW 2011 (information gathered in 2012) that have a recruitment site and 63.15\% of the BCW 2018 (information gathered in 2019) with on-line recruitment via their website.

In the BCW 2018, individual analysis was performed of the workforces of the total of employees of the 100 companies, leading to an indication that $47 \%$ were born after 1981 (the distribution is $42 \%$ Millennials and 5\% Generation Z).

\subsection{Classification and Frequency of Communication of the Different Components of the Benefits Offered to Employees}

After collecting the data from all of the best companies to work for which have a Benefits Offered to Employees section, a classification of the measures in Table 1 is made with the review of literature [41-50] and consultation with academic and professional colleagues who are experts in this subject. The quantification of the measures and their evolution is presented in Table 2.

Table 2. Benefits offered to employees in the BCW 2011 and BCW 2018. Source: drawn up by the authors.

\begin{tabular}{|c|c|c|c|c|c|c|}
\hline \multicolumn{7}{|c|}{ NON-ECONOMIC BENEFITS } \\
\hline & MEASURE & $\begin{array}{c}\text { BCW } 2011 \\
(\%)(N=80) \\
\end{array}$ & $\begin{array}{c}\text { BCW } 2018 \\
(\%)(N=60) \\
\end{array}$ & $\begin{array}{c}\text { EVOLUTION } \\
(\%)\end{array}$ & $\begin{array}{c}\text { DIFFERENCE } \\
(\%)\end{array}$ & $\begin{array}{c}\text { DIFFERENCE } \\
(\%)\end{array}$ \\
\hline Employee & $\begin{array}{c}\text { EAP } \\
\end{array}$ & 43.75 & 41.67 & -2.08 & \multirow{2}{*}{-21.67} & \multirow{8}{*}{27.91} \\
\hline wellbeing & WORK-LIFE BALANCE TRAINING & 21.25 & 1.66 & -19.59 & & \\
\hline Company & RECOGNITION & 20 & 16.67 & -3.33 & & \\
\hline commitment & ERP & 10 & 5 & -5 & -8.33 & \\
\hline \multirow{4}{*}{ Flexibility } & REMOTE WORKING & 5 & 8.33 & 3.33 & \multirow{4}{*}{57.92} & \\
\hline & SABBATICALS & 13.75 & 8.33 & -5.42 & & \\
\hline & FLEXI-HOURS & 22.5 & 28.33 & 5.83 & & \\
\hline & LEAVE & 22.5 & 76.67 & 54.17 & & \\
\hline \multicolumn{7}{|c|}{ ECONOMIC BENEFITS } \\
\hline & MEASURE & $\begin{array}{c}\text { BCW } 2011 \\
(\%)\end{array}$ & $\begin{array}{c}\text { BCW } 2018 \\
(\%)\end{array}$ & $\begin{array}{c}\text { EVOLUTION } \\
(\%)\end{array}$ & $\begin{array}{c}\text { DIFFERENCE } \\
(\%)\end{array}$ & $\begin{array}{c}\text { DIFFERENCE } \\
(\%)\end{array}$ \\
\hline \multirow{3}{*}{ Saving } & STUDY FEES & 46.25 & 48.33 & 2.08 & \multirow{3}{*}{-4.58} & \\
\hline & COMPANY DISCOUNTS & 36.25 & 35 & -1.25 & & \\
\hline & DISCOUNTS/OTHER COMPANIES & 23.75 & 18.33 & -5.42 & & \\
\hline \multirow{3}{*}{$\begin{array}{l}\text { Support in } \\
\text { performing } \\
\text { work }\end{array}$} & CAFETERIA \& MEALS & 22.5 & 20 & -2.5 & \multirow{3}{*}{7.08} & \\
\hline & FITNESS \& MASSAGES & 33.75 & 48.33 & 14.58 & & \\
\hline & TRANSPORT \& PARKING & 20 & 15 & -5 & & \\
\hline \multirow{3}{*}{$\begin{array}{l}\text { Insurance } \\
\text { cover }\end{array}$} & HEALTH INSURANCE & 90 & 95 & 5 & \multirow{3}{*}{-25.83} & -31.67 \\
\hline & LIFE INSURANCE & 72.5 & 43.33 & -29.17 & & \\
\hline & PENSION PLANS & 85 & 83.33 & -1.67 & & \\
\hline \multirow{4}{*}{$\begin{array}{l}\text { Facilitation } \\
\text { of personal } \\
\text { life }\end{array}$} & HOME HELP & 11.25 & 8.33 & -2.92 & \multirow{4}{*}{2.92} & \\
\hline & ASSISTANCE/ELDERLY & 12.5 & 16.67 & 4.17 & & \\
\hline & CHILDCARE/CHILD ASSISTANCE & 28.75 & 30 & 1.25 & & \\
\hline & ADOPTION & 36.25 & 36.67 & 0.42 & & \\
\hline \multirow{2}{*}{ Participation } & PROFIT PARTICIPATION & 13.75 & 8.33 & -5.42 & \multirow{2}{*}{-11.25} & \\
\hline & SHARES & 22.5 & 16.67 & -5.83 & & \\
\hline
\end{tabular}




\subsection{Sustainable Benefits}

As more sustainable benefits, we should point out those of the employee assistance program block; commitment measures (employee/organization); flexibility measures, insurance cover and measures to facilitate personal life and also the transport and car parking benefit.

In global terms, we should highlight the fact that in the BCW 2018, there is an increase of $27.71 \%$ of the presence of non-economic benefits and a drop in the frequency of publication of economic benefits $(31.67 \%)$ in comparison to the BCW 2011. The following results are also noteworthy:

1. In the BCW 2011, the three most frequently found benefits offered to employees belong to the insurance cover section, followed in fourth place by the study fee reimbursement measures. The least widespread benefits in 2011 were the remote working options and reference programs for new candidates.

2. In the BCW 2018, the two benefits offered to employees that were most frequently found belong to the insurance cover block (health insurance and pension plans), with life insurance losing importance, followed in third place by the offer of extraordinary leave extending beyond that which is offered on a mandatory basis and in fourth place, study fee reimbursement measures. The least widespread benefits in this section were training for attaining work-life balance and reference programs for new candidates.

3. As for the evolution of the presence of the benefits offered to employees on the websites of the BCWs, the following are worthy of mention:

- The largest increases in frequency were in Leave, which rise $54 \%$, followed by measures related to physical wellbeing, both in terms of exercise and massages, and then the benefit of being able to enjoy flexible working hours.

- The largest drops in presence on sites are life insurance policies (29.17\%), training offered by the company to balance work and family life, and programs geared towards ownership of shares by company employees. It is extremely relevant that we highlight the fact that the two direct benefits of the economic benefits section, participation and shares, are amongst the five benefits with the greatest decline in presence on recruitment websites.

- In sustainability, some remarkable data are the growth of the flexibility block (57.92\%), measures for assistance with personal life $(2.92 \%)$ and the fact that health insurance cover is the benefit with the greatest presence both in 2011 and in 2018, offered by $90 \%$ of the companies studied in 2011 and $95 \%$ in 2018. As we have indicated, life insurance drops.

\subsection{Results of the Evaluations of Potential Candidates}

Below, we present the results of the questionnaire regarding evaluation of the importance of benefits offered to employees for potential candidates in comparison to other HR activities and policies, and their evaluation of the different benefits offered to employees.

In Figure 1, we can see that the information on benefits offered to employees is second in importance regardless of the generation the candidates belong to (Millennials or Z), with the most highly-valued information being that related to the careers plan the company offers for candidates to move up in the organization. It is a content block appreciated by candidates above and beyond the general salary system.

With regard to the evaluation of the different benefits offered to employees (Figures 2 and 3), the best rating was obtained by measures related to employee recognition programs (both in the economic benefits and the non-economic benefits). Within the non-economic benefits, we should also highlight the relevance of the evaluation of flexible working hours (second place) and the fact that both periods of leave exceeding the legally established periods and the possibility of remote working obtain a higher-than-average rating for this block. This points towards the importance of the block (flexibility) 
for the new candidates. All of this concurs with the high rating candidates award to measures which also have a high sustainability content.

Within the economic benefits, we should point out that the financing measures for matters related to employees' commute to work is the most highly rated, followed by the insurance cover section and the measures regarding reimbursement of study fees and discounts on company products and services.

\section{Discussion}

The use of websites by companies is widespread. Companies strive for the best talent, and e-recruitment is an essential part of this process. One of the most important sections of these websites refers to Human Resources. It is the section called "Careers". Within it, there is a section called "Benefits Offered to Employees" which provides information on the company's HR activities and has been studied very little to date. This article sheds some light on the importance of this section in the e-recruitment process. An analysis of the information offered may demonstrate companies' interest in being attractive for prospective employees, and their adaptation to the demands of new generations of candidates, who are particularly interested in sustainability.

We can assert that the Employee Benefits Section is used by most BCWs with a recruitment site. It is a section that enables them to offer any information the company desires, with a design and management that can serve the interests of the company. Over half of the recruitment sites of the BCW 2018 disseminate information for potential candidates in this way, having formerly reached $80 \%$ in the BCW 2011. This drop may be due to an increased utilization of social media, such as LinkedIn, as recruitment tools. Moreover, the information published in this section on benefits offered to employees is rated very highly by potential candidates, indeed, we may deduce this from the data from our questionnaire. In said data, the value of this information is recognized in terms of importance for potential candidates when they apply for a job, awarding it second place (first place is for information on career plans), over and above the information on the general salary system. This makes it an ideal section for conveying certain values that attract new generations, such as sustainability values [55], which are capable of creating an employer brand [25].

By analyzing the contents of the Benefits Offered to Employees section, we conclude that there are two clearly differentiated blocks, which we call Economic Benefits and Non-Economic Benefits. This is a classic distinction in the literature on this area [50]. Both sets consist of different groups of measures and are rated with different levels of importance by potential candidates, with non-economic benefits obtaining a higher-than-average rating. The different studies mentioned in the Demands and Sustainability of the Millennial and Z Generations section point to preferences of the new generations oriented towards non-economic benefits. This may indicate that companies publish information on human resources activities designed to adapt and be attractive within the labor market of the new generations $[5,28]$.

When we compare the alignment of the benefits offered to employees communicated by companies with the values and preferences in terms of the working conditions of the new generations of candidates, we can affirm that organizations must, in order to attract the most suitable candidates, present relevant measures that are competitive from a purely economic perspective. However, these measures must also be important for the personal experience of employees (such as flexibility measures, commitment or insurance coverage) and in keeping with sustainability values [26]. One could say that in general, there is a certain alignment of the demands of the new generations with the information published in the Benefits Offered to Employees section. This occurs in areas such as skill development and training, as well as in benefits related to sustainability. In this regard, just as candidates' concern for sustainability has increased, so has the presence of information on sustainable benefits in the website section studied. The new generations are aware of the complexity of the world we live in and the need for solid training to decipher it, as well as the importance of the involvement of everybody in the struggle for sustainability. From a practical point of view, in our opinion, this alignment between what 
companies offer and what new generations are looking for is an important lesson that BCWs can pass on to other companies in order to secure the right talent in today's world.

Our results indicate that the social dimension of sustainability is related to the wellbeing of employees, their quality of life at work, and their alignment with the new predominant values. We believe that the new generations of candidates are very aware of the threats that our environment and our world are under at present, and therefore they are developing ever-greater sustainability values and showing themselves to be increasingly demanding in terms of the presence of these sustainability values in the organizations they work in. Thus, these organizations respond in turn by communicating these values [34] and becoming attractive for the aforementioned generations.

In our opinion, we must highlight the fact that in the BCW 2018, there is an increase in the presence of non-economic benefits and a drop in the frequency of publication of economic benefits in comparison to the BCW 2011. This reinforces the idea that companies strengthen the attraction and retention of workers with measures that do not involve economic commitments [61]. This piece of data was already mentioned previously when we indicated that the new generations also rate non-economic benefits more highly [28]. Very likely the crisis that we underwent in recent years has had an influence in this regard, as companies may have been forced to offer other activities to compensate for the reduction in economic benefits [62], and also the weight of the values of the new generations has changed, as they have altered their preferences in terms of working conditions, and their goal is to prioritize time which they can devote to themselves. The truth is that it may also be a symptom of the change that is taking place in the labor market through the so-called 4.0 revolution (human cloud). What we are clear about is that in terms of the aspect we are dealing with here, it would appear that both parties can benefit.

With regard to the evolution of sustainable benefits, we can see how, in the block of flexibility measures, all of the latter increase except for the possibility of requesting sabbaticals, and we should emphasize that this is the block with the most growth. Within flexibility, the rise in leave is extremely important, coming to occupy third place in terms of most frequently disseminated contents in the BCW 2018 (only behind health and pension plans). As indicated above, this may be explained by the interest new generations have in their quality of life at work and organizations' interest in the wellbeing of their employees. This idea is also reflected clearly in the results of the questionnaire on the evaluations of potential candidates, when we observe the results referring to flexible working hours, the possibility of remote working, and longer periods of leave than those legally established. We should not forget that by now, $47 \%$ of the employees of the BCW belong to the Millennial and $\mathrm{Z}$ generations. Another piece of data from which findings are revealed is that referring to the increase in cover related to employee health in the period studied. Moreover, this is the most-disseminated content both in the BCW 2011 and the BCW 2018. We believe this can be explained easily by the need to reach a minimum level of health protection on the part of employees.

\section{Conclusions}

In this multi-method study, we use both content analyses of the employee benefits described on corporate websites at two points in time several years apart, and surveys of young job seekers in both those years. In spite of the importance of the information provided in this section in terms of attracting new candidates during the recruitment process, there are no papers which study either the type of content being provided or its evolution over time, or which delimit the appraisal made of said benefits by the new generations. In this regard, this study seeks to fill this gap in the literature and contribute to the knowledge and improvement of on-line recruitment through corporate websites.

By way of a final conclusion, the results obtained in this study concur with the literature consulted in terms of the importance of the information presented through corporate websites in attracting potential employees, the results of the reports on the Millennials and Z generations, and in the results of our study on the evaluations of potential candidates. In addition, companies are clearly intensifying sustainability-related measures such as flexibility of working days, actions aimed at facilitating the personal life of employees or health-related insurance cover. 
We can see how companies have evolved both in the importance they bestow on communicating information on their websites via the Benefits Offered to Employees section, and in the type of information they publish, which they try to adapt to the new tastes and requirements of the new generations of potential employees. In this regard, the largest gap we have perceived was in the recognition measures (in the $\mathrm{BCW}$ ' 18 , the companies informing that they have recognition programs have dropped by $3.33 \%$, from $20 \%$ to $16.67 \%$ ), and therefore companies are advised to intensify the communication of this type of measures.

\section{Limitations and Future Research}

In spite of the fact that, on the employment offer side, we have worked with the entire population, in the case of the company recruitment sites at two different points in time, this study has certain limitations. On the one hand, on the side of the job seekers, we worked with the self-informed evaluations of potential candidates. Said evaluations are therefore subject to the participants' level of understanding of the survey measures (although they were provided with specific examples in the surveys) and to their knowledge of their own preferences for different workers' remuneration measures. In addition, the composition of the sample is subject to the bias of being primarily candidates seeking their first job. However, since the evaluations were made by the new generations of candidates, we believe that our survey was appropriate for the goals of our study, which were to explore the compensation measures that may influence candidates' selections when submitting an on-line application for a post via the website. Further, although our sample size was sufficient for making statistical analyses, this was an exploratory pilot study. As such, it was designed to construct an initial conceptual framework of the benefits offered to employees by companies which already stand out for their excellent personnel management and their rating by the new generations.

Additional studies need to be carried out in order to verify the findings of this study and confirm the validity of this framework of classification of benefits offered to employees and the future evolution of adaptation of contents by companies.

Another limitation, on the side of the job seekers, is related to the fact that no observation was made of the behavior of the candidates when they access the recruitment sites and analyze the contents provided by the companies. Such observation would verify whether their ratings of each of the economic and non-economic benefits would predict their true behavior in sending in the job application or refraining from doing so. Therefore, future studies must research the relationship between the self-informed evaluations of individuals and their actual behavior in on-line recruitment.

The findings of this study should be an invitation for future research to improve knowledge of on-line recruitment and of benefits offered to employees as an element for capturing new candidates.

The main contribution of this article is based on the concept of the importance of the fit between information provided by employers and preferences of the new candidates (Millennials and Z Generation). In this sense, the section usually called "Benefits Offered to Employees" in the corporate websites is widely used by the best companies to work for and covers a wide range of different benefits. Finally, Companies should consider incorporating sustainability values as an area demanded by the new generations.

Author Contributions: All authors contributed equally to this work. The research was designed by M.B.-M., J.L.T.-J. and Ó.R.G.-L. The data was collected by M.B.-M., Ó.R.G.-L. and J.L.T.-J. Analysis of data was performed by J.L.T.-J. Finally, the paper was written and edited by Ó.R.G.-L. and M.B.-M. All authors read and approved the final manuscript.

Funding: This research was funded by the Government of Extremadura-Spain (Consejería de Economía e Infraestructura) and FEDER aid.

Conflicts of Interest: The authors declare no conflict of interest. 


\section{References}

1. García Cali, E.; Barros-Arrieta, D.; Valle-Ospino, A. Endomarketing desde el paradigma de la sostenibilidad organizacional: Una revisión de la literatura. Desarro. Gerenc. 2018, 10. [CrossRef]

2. Young, J.; Foot, K. Corporate E-Cruiting: The Construction of Work in Fortune 500 Recruiting Web Sites. J. Comput. Mediat. Commun. 2005, 11, 44-71. [CrossRef]

3. Cober, R.T.; Brown, D.J.; Keeping, L.M.; Levy, P.E. Recruitment on the Net: How do organizational Web site characteristics influence. J. Manag. 2004, 30, 623-646. [CrossRef]

4. Kashive, N.; Khanna, V.T. Building Employee Brand Equity to influence Organization Attractiveness and Firm Performance. Int. J. Bus. Manag. 2017, 12, 207-219. [CrossRef]

5. Deloitte The Deloitte Millennial Survey. 2018, pp. 1-32. Available online: https://www2.deloitte.com/co/es/ pages/about-deloitte/articles/millennialsurvey2018.html (accessed on 25 February 2019).

6. Eveleth, D.M.; Baker-Eveleth, L.J.; Stone, R.W. Potential applicants' expectation-confirmation and intentions. Comput. Hum. Behav. 2015, 44, 183-190. [CrossRef]

7. Barroso, A.; González-López, Ó.R.; Sanguino, R.; Buenadicha-Mateos, M. Analysis and evaluation of the largest 500 family firms' websites through PLS-SEM technique. Sustainability 2018, 10, 557. [CrossRef]

8. Borstorff, P.; Marker, M.; Bennett, D. Online Recruitment Attitude and behavious of Job Seekers. J. Strateg. E-Commer. 2007, 5, 1-23.

9. Laumer, S.; Eckhardt, A.; Weitzel, T. Electronic human resources management in an e-business environment. J. Electron. Commer. Res. 2010, 11, 240.

10. Melanthiou, Y.; Pavlou, F.; Constantinou, E. The Use of Social Network Sites as an E-Recruitment Tool. J. Transnatl. Manag. 2015, 20, 31-49. [CrossRef]

11. Andrés-Reina, M.P. Nuevos procedimientos en el proceso empresarial de provisión de candidatos: El reclutamiento online. Cuad. Cienc. Económicas Empresariales 2004, 47, 89-110.

12. Derous, E.; De Fruyt, F. Developments in Recruitment and Selection Research. Int. J. Sel. Assess. 2016, 24, 1-3. [CrossRef]

13. Alles, M. Dirección Estratégica de Recursos Humanos Vol II-Casos; Ediciones Granica: Buenos Aires, AR, USA, 2005.

14. Maurer, S.D.; Liu, Y. Developing effective e-recruiting websites: Insights for managers from marketers. Bus. Horiz. 2007, 50, 305-314. [CrossRef]

15. Backhaus, K.; Tikoo, S. Conceptualizing and researching employer branding. Career Dev. Int. 2004, 9, 501-517. [CrossRef]

16. Cober, R.T.; Brown, D.J.; Blumental, A.J.; Doverspike, D.; Levy, P. The quest for the qualified job surfer: It's time the public sector catches the wave. Public Pers. Manag. 2000, 29, 479-496. [CrossRef]

17. Gale, S.F. Internet recruiting: Better, cheaper, faster. Workforce 2001, 80, 74-77.

18. Highhouse, S.; Lievens, F.; Sinar, E.F. Measuring attraction to organizations. Educ. Psychol. Meas. 2003, 63, 986-1001. [CrossRef]

19. Jones, C.; Hecker, R.; Holland, P. Recruitment and the Internet: Possibilities and Pitfalls; Monash University Faculty of Business and Economics: Melbourne, Australia, 2002; pp. 1-9.

20. Lang, S.; Laumer, S.; Maier, C.; Eckhardt, A. Drivers, Challenges and Consequences of E-Recruiting: A literature review. In Proceedings of the 49th SIGMIS Annual Conference on Computer Personnel Research, San Antonio, TX, USA, 19-21 May 2011; pp. 26-35.

21. Lee, S.; Lee, S.; Park, Y. A prediction model for success of services in e-commerce using decision tree: E-customer's attitude towards online service. Expert Syst. Appl. 2007, 33, 572-581. [CrossRef]

22. Maurer, S.D.; Howe, V.; Lee, T.W. Organizational recruiting as marketing management: An interdisciplinary study of engineering graduates. Pers. Psychol. 1992, 45, 807-833. [CrossRef]

23. Stone, D.L.; Stone-Romero, E.F.; Lukaszewski, K.M. The impact of cultural values on the acceptance and effectiveness of human resource management policies and practices. Hum. Resour. Manag. Rev. 2007, 17, 152-165. [CrossRef]

24. Cable, D.M.; Graham, M.E. The determinants of job seekers' reputation perceptions. J. Organ. Behav. 2000, 21, 929-947. [CrossRef]

25. Boşcai, B.G. The evolution of e-recruitment: The introduction of online recruiter. In Management and Organization: Concepts, Tools and Applications; Pearson: Harlow, UK, 2017. 
26. Boudreau, J.W.; Ramstad, P.M. Talentship, talent segmentation, and sustainability: A new HR decision science paradigm for a new strategy definition. Hum. Resour. Manag. 2005, 44, 129-136. [CrossRef]

27. Constantin, A. The antecedents of e-satisfaction and e-loyalty and the relationship between them. Timis. J. Econ. 2012, 5, 236-252.

28. ManpowerGroup. Manpower Group Millennial Careers: 2020 Vision: Facts, Figures and Practical Advice from Workforce Experts; ManpowerGroup: Milwaukee, WI, USA, 2016.

29. Cable, D.M.; Judge, T.A. Person-organization fit, job choice decisions, and organizational entry. Organ. Behav. Hum. Decis. Process. 1996, 67, 294-311. [CrossRef]

30. Kristof, A.L. Person-organization fit: An integrative review of its conceptualizations, measurement, and implications. Pers. Psychol. 1996, 49, 1-49. [CrossRef]

31. Schneider, B. The people make the place. Pers. Psychol. 1987, 40, 437-453. [CrossRef]

32. Highhouse, S.; Hoffman, J.R. Organizational attraction and job choice. Int. Rev. Ind. Organ. Psychol. 2001, 16, 37-64.

33. Petty, R.E.; Cacioppo, J.T.; Schumann, D. Central and peripheral routes to advertising effectiveness: The moderating role of involvement. J. Consum. Res. 1983, 10, 135-146. [CrossRef]

34. Cole, N.D.; Flint, D.H. Perceptions of distributive and procedural justice in employee benefits: Flexible versus traditional benefit plans. J. Manag. Psychol. 2004, 19, 19-40. [CrossRef]

35. Gumbus, A.; Johnson, S.D. The balanced scorecard at Futura Industries. Strateg. Financ. 2003, 85, 36.

36. Ehrhart, K.H.; Ziegert, J.C. Why are individuals attracted to organizations? J. Manag. 2005, 31, 901-919. [CrossRef]

37. McNall, L.A.; Masuda, A.D.; Nicklin, J.M. Flexible work arrangements, job satisfaction, and turnover intentions: The mediating role of work-to-family enrichment. J. Psychol. 2009, 144, 61-81. [CrossRef]

38. Madero-Gómez, S.M.; Zárate-Solís, I.A. La sostenibilidad desde una perspectiva de las áreas de negocios. Cuad. Adm. 2016, 32, 7-19. [CrossRef]

39. Contreras, O.E.; Rozo, I. Teletrabajo y sostenibilidad empresarial. Una reflexión desde la gerencia del talento humano en Colombia. Suma Neg. 2015, 6, 74-83. [CrossRef]

40. Nazario, R. Beneficios y motivación de los empleados. Inven. Rev. Investig. Académica 2006, 17, $133-145$.

41. Prat, R.; Tovar, P. Modelo de compensación total: La motivación más allá de la retribución. Cap. Hum. 1999, 118, 24-27.

42. Roche, A.; Kostadinov, V.; Cameron, J.; Pidd, K.; McEntee, A.; Duraisingam, V. The development and characteristics of Employee Assistance Programs around the globe. J. Workplace Behav. Health 2018, 33, 168-186. [CrossRef]

43. Williams, C.C. Commitment Measures; Edward Elgar Publishing Ltd.: Cheltenham, UK, 2014; p. 199.

44. Felstead, A.; Henseke, G. Assessing the growth of remote working and its consequences for effort, well-being and work-life balance. New Technol. Work Employ. 2017, 32, 195-212. [CrossRef]

45. Hunter, P. Remote working in research an increasing usage of flexible work arrangements can improve productivity and creativity. EMBO Rep. 2019, 20, e47435. [CrossRef]

46. Altmann, S.; Kroell, C. Understanding employees' intention to take sabbaticals: Analyzing the role of supportive supervisors. Pers. Rev. 2018, 47, 882-899. [CrossRef]

47. Berry, L.L.; Mirabito, A.M.; Baun, W.B. What's the Hard Return on Employee Wellness Programs? Harv. Bus. Rev. 2010, 88, 104-112.

48. Fuchs, R.M.; Sato, S.S. El sueldo no es suficiente para atraer y retener a los mejores. J. Bus. 2009, 1, 91-106.

49. Soler I Blanch, G.; Moreno Pérez, C.M. Inversión en la retribución no tangible para la conciliación laboral. Intang. Cap. 2013, 9, 1021-1041.

50. Dolan, S.L.; Schuler, R.S.; Valle-Cabrera, R. La Gestión de los Recursos Humanos; McGraw Hill: New York, NY, USA, 1999.

51. Mondy, R.W. Human Resource Management, 11th ed.; Pearson Education, Inc.: London, UK, 2010.

52. Charrier, K. Marketing strategies for attracting and retaining Generation X police officers. Police Chief 2000, $67,45-51$.

53. Lyons, S.; Kuron, L. Generational differences in the workplace: A review of the evidence and directions for future research. J. Organ. Behav. 2014, 35, S139-S157. [CrossRef]

54. Carlson, H.C. Changing of the Guard: A New Generation of Teacher Leaders Will Raise Quality-of-Life Priorities. Sch. Adm. 2004, 61, 36. 
55. Dencker, J.C.; Joshi, A.; Martocchio, J.J. Towards a theoretical framework linking generational memories to workplace attitudes and behaviors. Hum. Resour. Manag. Rev. 2008, 18, 180-187. [CrossRef]

56. Lightspeed Recycling in the Workplace: A Millennial View. 2017. Available online: https://www.fmmedia. com.au/sectors/recycling-workplace-millennial-view/ (accessed on 30 April 2018).

57. Davis, J.F. Effectiveness of Internet Advertising by Leading National Advertisers; Lawrence Erlbaum Associates: Mahwah, NJ, USA, 1999.

58. Galanaki, E. The decision to recruit online: A descriptive study. Career Dev. Int. 2002, 7, 243-251. [CrossRef]

59. Bethlehem, J.; Biffignandi, S. Handbook of Web Surveys; John Wiley \& Sons: Hoboken, NJ, USA, 2011; Volume 567.

60. Wright, K.B. Researching Internet-Based Populations: Advantages and Disadvantages of Online Survey Research, Online Questionnaire Authoring Software Packages, and Web Survey Services. J. Comput. Mediat. Commun. 2005, 10. [CrossRef]

61. Schlechter, A.; Thompson, N.C.; Bussin, M. Attractiveness of non-financial rewards for prospective knowledge workers: An experimental investigation. Empl. Relat. 2015, 37, 274-295. [CrossRef]

62. Gunnigle, P.; Lavelle, J.; Monaghan, S. Weathering the storm? Multinational companies and human resource management through the global financial crisis. Int. J. Manpow. 2013, 34, 214-231. [CrossRef]

(C) 2019 by the authors. Licensee MDPI, Basel, Switzerland. This article is an open access article distributed under the terms and conditions of the Creative Commons Attribution (CC BY) license (http://creativecommons.org/licenses/by/4.0/). 